\title{
Resveratrol May Protect Plasma Proteins from Oxidation under Conditions of Oxidative Stress In Vitro
}

\author{
Kanti Bhooshan Pandey and Syed Ibrahim Rizvi*
}

\author{
Department of Biochemistry, University of Allahabad, Allahabad 211002, India
}

\begin{abstract}
As proteínas são vulneráveis ao estresse oxidativo, ou seja, ao ataque das espécies de oxigênio reativo causando consequentemente, a oxidação e formação de fragmentos carbonilados, produtos avançados de oxidação proteica (AOPPs) e, outros produtos indesejados da oxidação. Resveratrol, uma fitoalexina polifenólica encontrada abundantemente nas uvas e no vinho tinto, é um dos produtos naturais extensivamente estudados, com atividades biológicas como cardio-protetor, neuro-protetor, anti-envelhecimento, e anti-cancer. A maioria dos efeitos desses estilbenos é atribuída a sua propriedade antioxidante. No estudo atual nós avaliamos o papel do resveratrol na proteção à oxidação proteica no plasma após a indução in vitro ao estresse oxidativo. O estresse oxidativo induzido foi efetuado incubando-se o plasma com peróxido de terc-butila $10^{-5} \mathrm{~mol} \mathrm{~L}^{-1}$, o que acarretou em um aumento significativo das proteínas carboniladas do plasma (PCO) e dos AOPPs, e na diminuição dos grupos sulfidrilas (-SH). A presença do resveratrol protegeu as proteínas da oxidação, efeito esse dependente da concentração. Com base em nossos ensaios, os efeitos mostrados pelo resveratrol corroboraram evidências de uma propriedade antioxidante forte.
\end{abstract}

Proteins are vulnerable to oxidative stress; attack by reactive oxygen species causes oxidation and formation of carbonyl moieties, advanced oxidation protein products (AOPPs) and other undesired oxidation products. Resveratrol, a polyphenolic phytoalexin found abundantly in grapes and red-wine, is one of the most extensively studied natural products, with wide ranging biological activities including cardio-protective, neuro-protective, anti-aging, and anti-cancer. Most of the effects of these stilbenes are attributed to their antioxidant property. In the present study we have evaluated the role of resveratrol in the protection of plasma protein oxidation after induction of in vitro oxidative stress. Inducing oxidative stress by incubating with $10^{-5} \mathrm{~mol} \mathrm{~L}^{-1}$ tert-butylhydroperoxide caused a significant elevation in plasma protein carbonyls (PCO) and AOPPs, and decrease in -SH groups. Presence of resveratrol protected proteins from oxidation, an effect which was concentration dependent. On the basis of our experiments and effects shown by resveratrol we substantiate existing evidence for the strong antioxidant property of resveratrol.

Keywords: resveratrol, oxidative stress, AOPPs, -SH groups, protein carbonyls

\section{Introduction}

Oxidative stress is considered as the main cause in development of several chronic human diseases including cancer, diabetes, hypertension, cardiovascular diseases and aging. ${ }^{1,2}$ Reactive oxygen species (ROS) are generated under normal metabolic processes and are involved to some extent as signaling molecules and defense mechanisms as seen in phagocytosis, neutrophil function, and shear-stress induced vasorelaxation, however their excess/uncontrolled generation is deleterious which leads to oxidative stress. ${ }^{3}$ ROS may damage all types of biological molecules. Oxidative

\footnotetext{
*e-mail: sirizvi@gmail.com,rzv@ rediffmail.com
}

damages to proteins, lipids or DNA may all be seriously deleterious and may be concomitant. However, proteins are possibly the most immediate vehicle for inflicting oxidative damage on cells because they are often catalysts rather than stoichiometric mediators; hence, the effect of damage to one molecule is greater than stoichiometric. ${ }^{4}$

It is well established that exposure of proteins to reactive oxygen species (ROS) can alter the physical and chemical structure of the proteins causing oxidation of side-chain groups, protein scission, backbone fragmentation, crosslinking and unfolding. These alterations are consequent to formation of new reactive groups, generation of protein carbonyls (PCO), oxidation of -SH groups, formation of dityrosine containing cross-linked protein products known 
as advanced oxidation protein products (AOPPs) and many others. $^{5-7}$

There is overwhelming evidence to suggest that nutritional sources of antioxidants, such as fruits, vegetable, tea or wine would attenuate tissue damage caused by oxidative challenges. ${ }^{8}$ Polyphenolic compounds, abundant in these nutritional sources, could play a major role in enhancing the antioxidant system. ${ }^{9,10}$ Resveratrol, (trans-3,5,4'-trihydroxystilbene) is a polyphenolic phytoalexin present naturally in grapes, peanuts and red-wine. It has been reported to possess diverse biochemical and physiological actions, including estrogenic, antiplatelet, and anti-inflammatory properties. ${ }^{11}$ Recently resveratrol is found to be a highly potent antioxidant which could inhibit free radical generation in brain, spinal cord, liver and red cell membrane. ${ }^{12-15}$ However, depending on the concentration of the phytoalexin and the cell type, it has also been shown that resveratrol can exhibit pro-oxidant properties, leading to oxidative breakage of cellular DNA in the presence of transition metal ions such as copper. It has also been proposed that such a pro-oxidant action could be a common mechanism for anticancer and chemopreventive properties of resveratrol. ${ }^{16,17}$

In the present study, we have evaluated the in vitro effect of resveratrol on markers of protein oxidation: PCO, AOPPs and -SH groups (total thiol), in human plasma subjected to in vitro oxidative stress. The study was aimed to test the efficiency/efficacy of resveratrol to maintain redox status of plasma proteins.

\section{Experimental}

\section{Materials and methods}

\section{Collection of blood, isolation of plasma}

The protocol of study was in conformity with the guidelines of the Allahabad University Ethical Committee. Human venous blood from seventeen different healthy volunteers was obtained by venipuncture in heparin. Plasma was obtained by centrifuging the blood at $1800 \times g$ for $10 \mathrm{~min}$ at $4^{\circ} \mathrm{C}$.

\section{Induction of oxidative stress and in vitro experiments with resveratrol}

Oxidative stress was induced in vitro by incubating the plasma with $10^{-5} \mathrm{~mol} \mathrm{~L}^{-1}$ tert-butylhydroperoxide ( $t$-BHP) for $30 \mathrm{~min}$ at $37^{\circ} \mathrm{C}$. The procedure of induction of oxidative stress was similar to already published reports. ${ }^{15,18}$ The effect of resveratrol was evaluated by co-incubating the plasma with $t$-BHP and resveratrol at different doses for 30 min at $37{ }^{\circ} \mathrm{C}$. Parallel control experiments were also performed in which resveratrol was replaced with an equal amount of solvent.

\section{Determination of advanced oxidation protein products}

Determination of advanced oxidation protein products (AOPPs) in plasma was based on spectrophotometric detection according to Witko-Sarsat et al. ${ }^{6}$ Briefly, $200 \mu \mathrm{L}$ of diluted plasma (i.e. one volume of plasma + five volumes of phosphate-buffered saline (PBS)) as test; $200 \mu \mathrm{L}$ of chloramine-T solution $\left(0-100 \mu \mathrm{mol} \mathrm{L} \mathrm{L}^{-1}\right)$ for calibration and $200 \mu \mathrm{L}$ of phosphate buffered saline (PBS) as blank were taken in three separate tubes. $10 \mu \mathrm{L}$ of $1.16 \mathrm{~mol} \mathrm{~L}^{-1}$ potassium iodide and $20 \mu \mathrm{L}$ of acetic acid were added making the final volume of the assay medium to $2.3 \mathrm{~mL}$, absorbance was measured immediately at $340 \mathrm{~nm}$. The chloramine- $\mathrm{T}$ absorbance at $340 \mathrm{~nm}$ was linear within the range of 0 to $100 \mu \mathrm{mol} \mathrm{L}{ }^{-1}$. Readings were taken in triplicates of 17 independent experiments. Concentration

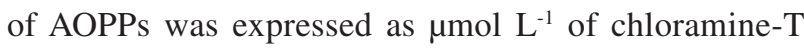
equivalents.

\section{Determination of plasma protein carbonyls}

Plasma protein carbonyls (PCO) content was measured according to procedure of Levine et al.. ${ }^{5}$ Plasma samples were taken in two tubes as test and control. $4.0 \mathrm{~mL}$ of $10 \mathrm{mmol} \mathrm{L}^{-1}$ 2,4-dinitrophenylhydrazine (DNPH) prepared in $2 \mathrm{~mol} \mathrm{~L}^{-1} \mathrm{HCl}$ was added to the test sample and $4.0 \mathrm{~mL}$ of $2 \mathrm{~mol} \mathrm{~L}^{-1} \mathrm{HCl}$, alone was added to the control sample. The contents were mixed thoroughly and incubated for $1 \mathrm{~h}$ in the dark at $37^{\circ} \mathrm{C}$. The tubes were shaken intermittently every $10 \mathrm{~min}$ to facilitate the reactions with proteins. After that, $20 \%$ TCA (m/v) was added to both tubes and the mixture left in ice for $10 \mathrm{~min}$. The tubes were then centrifuged at 3,500 rpm for $20 \mathrm{~min}$ to obtain the protein pellets. The supernatant was carefully aspirated and discarded. The protein pellets were washed three times with ethanol:ethyl acetate $(1: 1, \mathrm{v} / \mathrm{v})$ solution to remove unreacted DNPH and lipid remnants. Finally protein pellets were dissolved in $6 \mathrm{~mol} \mathrm{~L}^{-1}$ guanidine hydrochloride and incubated for $10 \mathrm{~min}$ at $37^{\circ} \mathrm{C}$. The insoluble materials were removed by centrifugation. PCO content was determined by measuring the absorbance of the supernatant at $370 \mathrm{~nm}$. Each sample was read against the control. Readings were taken in triplicates of 17 independent experiments. The PCO content was calculated by using an absorption coefficient (e) of 22,000 $\mathrm{M}^{-1} \mathrm{~cm}^{-1}$ and data was expressed in $\mathrm{nmol} \mathrm{L}^{-1}$ of plasma.

\section{Estimation of plasma -SH groups}

Plasma -SH groups (total thiols) were estimated according to Kitajima's method, ${ }^{19}$ based on the ability of 
the -SH group to reduce 5, 5'-dithiobis, 2-nitrobenzoic acid (DTNB) and form a yellow colored anionic product whose OD is measured at $412 \mathrm{~nm}$. Readings were taken in triplicates of 17 independent experiments. The concentration of the -SH group was expressed as $\mu \mathrm{mol} \mathrm{L}^{-1}$ of plasma.

\section{Statistical analysis}

Statistical analysis was performed using GraphPad Prism version 4.00 for Windows, GraphPad Software, San Diego, California, USA. The results are reported as means \pm SD. Statistical differences were analyzed using two-way ANOVA; and the differences were considered to be significant when $p<0.05$.

\section{Results and Discussion}

Reactive oxygen and nitrogen species such as superoxide anion, hydroxyl radicals, hydrogen peroxide, lipid peroxyl radicals, nitric oxide, and peroxynitrite, are generated in different cellular systems through enzymatic and non-enzymatic reactions. Many pathological conditions are associated with excessive production of these reactive species which can attack key proteins, lipids and DNA, alter signal transduction pathways, destroy membranes and subcellular organelles, and subsequently result in apoptosis and cell death. ${ }^{13}$

Proteins are likely to be major targets, as a result of their abundance in cells, plasma, and most tissues, and their rapid rates of reaction both with many radicals and with other oxidants (e.g., peroxides, excited states, peroxynitrite, chloramines, and ozone). It is of importance to consider that the extent of damage to any particular component does not necessarily correlate with the importance of such damage, the output of damage depends more upon the type of molecule getting damaged in comparison to quantity of damage. Thus a low level of damage to a critical species may be of much greater significance than massive damage to a nonessential target. ${ }^{20}$

Induction of oxidative stress in plasma in vitro by incubating with $t$-BHP $\left(10^{-5} \mathrm{~mol} \mathrm{~L}^{-1}\right)$ caused a significant $(p<0.001)$ increase in the PCO and AOPPs level and decrease in -SH group content compared with basal values. Incubation of plasma with resveratrol resulted in significant protection against the $t$-BHP-induced oxidative stress as evidenced by the decrease in AOPPs (Figure 1) and PCO levels (Figure 2) and increase in -SH groups content (Figure 3). It was observed that the effect of resveratrol was dose/concentration dependent, a higher effect was observed with increase in concentration. Resveratrol protected generation of PCO and depletion of -SH groups at lower concentration $\left(0.1 \mu \mathrm{mol} \mathrm{L} \mathrm{L}^{-1}\right)$, however effect of resveratrol in protection of generation of AOPPs was not significant at this concentration.

The presence of carbonyl groups in proteins has been used as a marker of ROS-mediated protein oxidation. Generation of protein carbonyl derivatives occurs by oxidative modifications of proteins either by the $\alpha$-amidation pathway or by oxidation of glutamyl side chains, which leads to formation of a peptide in which the $\mathrm{N}$-terminal amino acid is blocked by an $\alpha$-ketoacyl

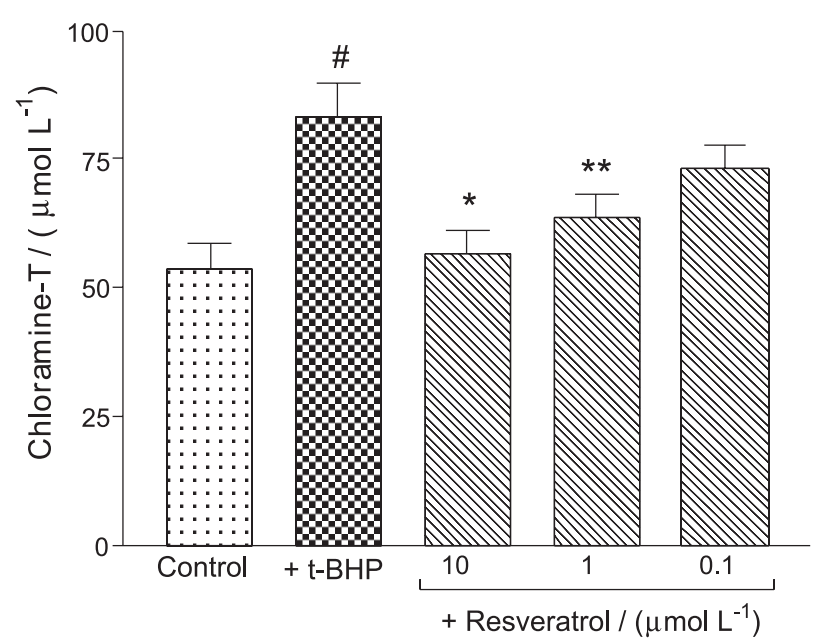

Figure 1. Concentration/dose dependent effect of resveratrol on $t$-BHP induced changes in plasma advanced oxidation protein products (AOPPs) content. Incubation with $t$-BHP caused an increase in AOPPs content. Treatment with resveratrol showed significant protection against $t$-BHP induced stress at concentrations of $10 \mu \mathrm{mol} \mathrm{L} \mathrm{L}^{-1}$ and $1 \mu \mathrm{mol} \mathrm{L} \mathrm{L}^{-1}$. The effect at $0.1 \mu \mathrm{mol} \mathrm{L^{-1 }}$ was not significant. AOPPs content is expressed as $\mu \mathrm{mol} \mathrm{L}-1$ of chloramine-T equivalents. \# $p<0.001$ compared with control, $* p<0.01$ and $* * p<0.05$ compared with $t$-BHP treated.

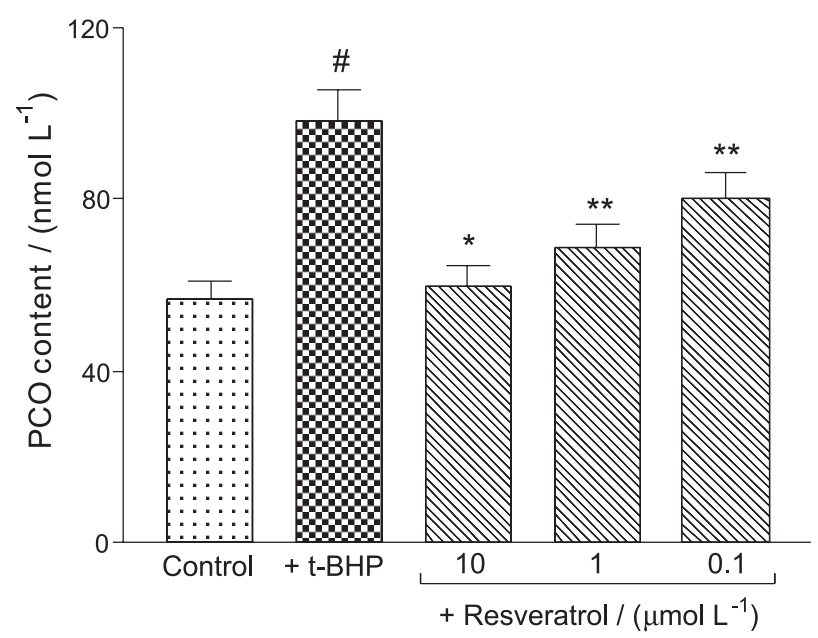

Figure 2. Concentration/dose dependent effect of resveratrol on $t$-BHP induced changes in plasma protein carbonyls (PCO) level. Incubation with $t$-BHP caused an increase in PCO level. Treatment with resveratrol showed significant protection against $t$-BHP induced stress at concentrations of

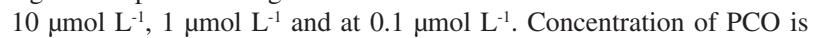
expressed as nmol L-1 of plasma. \# $p<0.001$ compared with control, $* p<0.001$ and $* * p<0.05$ compared with $t$-BHP treated. 


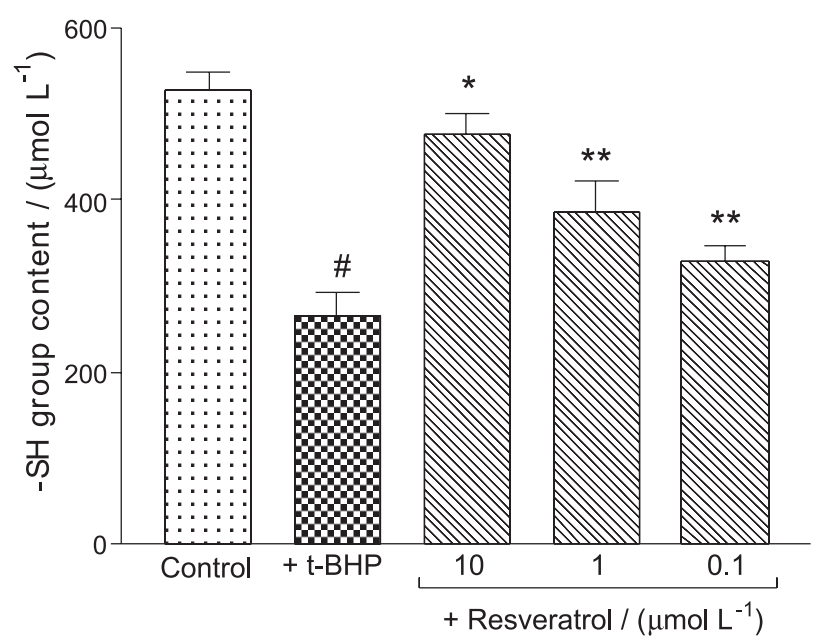

Figure 3. Concentration dependent effect of resveratrol on $t$-BHP induced changes in plasma -SH group content. Incubation with $t$-BHP caused a decrease in plasma -SH group content. Treatment with resveratrol shows significant protection against $t$-BHP induced stress at concentrations $10 \mu \mathrm{mol} \mathrm{L}{ }^{-1}, 1 \mu \mathrm{mol} \mathrm{L}^{-1}$ and $0.1 \mu \mathrm{mol} \mathrm{L}^{-1}$. The concentration of the -SH

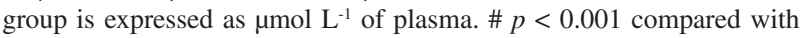
control, $* p<0.01$ and $* * p<0.05$ compared with $t$-BHP treated.

derivative. However, direct oxidation of lysine, arginine, proline, and threonine residues may also yield carbonyl derivatives. ${ }^{21}$ In addition, carbonyl groups may be introduced into proteins by reactions with aldehydes (4-hydroxy-2-nonenal, malondialdehyde) produced during lipid peroxidation..$^{22}$ Some protein damage is reversible, such as peroxiredoxin inactivation, methionine sulphoxide formation and $s$-nitrosylation. However other damages, for example oxidation of side-chains to carbonyl residues, appears to be irreversible and the protein is destroyed. ${ }^{1}$

The use of protein carbonyls as index of oxidative stress has some advantages in comparison with the measurement of other oxidation products because of the relative early formation and the relative stability of carbonylated proteins. ${ }^{4}$

AOPPs are proteins, predominantly albumin and its aggregates, damaged by oxidative stress and they contain abundant dityrosines, which allow cross-linking, disulphide bridges and carbonyl groups ${ }^{6}$ and are formed mainly by chlorinated oxidants; hypochlorous acid and chloramines resulting from myeloperoxidase activity. ${ }^{7,23}$ Protein oxidation products mediated by chlorinated species generated by an enzyme myeloperoxidase were found in the extracellular matrix of human atherosclerotic plaques and increased levels of AOPPs were described as an independent risk factor for coronary artery and renal diseases. ${ }^{23,24}$ Inhibition of formation of AOPPs and PCO by resveratrol directly advocates its strong antioxidant effect.

Protein sulphydryl groups play a prominent role in antioxidant reactions, and also in reactions of catalysis, regulation, electron transport and those preserving the correct structure of proteins..$^{25}$ The levels and mutual relations between different redox forms of thiols in plasma are decisive for the plasma redox capacity, which determines its proper function. For all these reasons, plasma thiols should be considered not only as metabolites transported between organs and tissues, but also as functionally important plasma components. ${ }^{26}$ Reduced concentration of -SH groups has been reported in several chronic diseases including aging and diabetes. ${ }^{2,9}$ Protection of - $\mathrm{SH}$ group oxidation by resveratrol at lower concentration not only proves its strong antioxidant potential but may also help in preserving the correct structure of proteins.

Several in vivo studies also prove the health protective biological activities of resveratrol. Resveratrol has been shown to increase plasma antioxidant capacity and inhibitory effect on the colon carcinogenesis in wistar rats. ${ }^{27}$ Systemic administration of resveratrol blocked the increase in platelet aggregation that was induced in the rabbits by a hypercholesterolaemic diet. ${ }^{28}$ In strokeprone, spontaneously hypertensive rats, resveratrol significantly reduces markers of oxidative stress such as glycated albumin in serum, and 8-hydroxyguanosine in urine. Furthermore, in guinea pigs, resveratrol was found to induce the activities of quinone reductase $1(\mathrm{QR} 1)$ and catalase in cardiac tissue, and decrease the concentration of ROS generated by menadione. ${ }^{29,30}$ Pace-Asciak et al. ${ }^{31}$ reported that trans-resveratrol can be absorbed from grape juice in biologically active quantities and in amounts that are likely to cause reduction in the risk of atherosclerosis. In 1999, Blaridi et al..$^{32}$ reported the stimulation of endogenous adenosine release by oral administration of quercetin and resveratrol in man. Resveratrol also causes an increase in plasma adenosine levels and blood nucleosides in human subjects. ${ }^{30}$ These results indicate that resveratrol can suppress pathological increases in the oxidation/ peroxidation of macromolecules in vivo.

In recent years, the antioxidative activity of food constituents has been investigated extensively in an effort to characterize their efficacy as natural dietary antioxidants. Our observation on the protective effect of resveratrol at the concentration 10 to $0.1 \mu \mathrm{mol} \mathrm{L} \mathrm{L}^{-1}$, on oxidation of plasma proteins under in vitro oxidative stress assumes significance because it has been reported that after consumption of resveratrol rich diet, the plasma value of resveratrol could be achieved in micromolar range..$^{33} \mathrm{Also}$, the effects exerted by resveratrol get importance because the maintenance of protein redox status is of fundamental importance for cell function, since structural changes in proteins are considered to be among the molecular mechanisms leading to endothelial dysfunction and development of many chronic diseases including aging. ${ }^{7,34}$ On the basis 
of our experiments and effects shown by resveratrol we substantiate existing evidence for the strong antioxidant property of resveratrol.Our findings provide an additional evidence to the possible mechanism(s) by which resveratrol exerts health beneficial effects.

\section{Acknowledgment}

Kanti Bhooshan Pandey is a recipient of Senior Research Fellowship form Council of Scientific \& Industrial Research (CSIR), New Delhi, India.

\section{References}

1. Halliwell, B.; Gutteridge, J. M. C.; Free Radicals in Biology and Medicine, $4^{\text {th }}$ ed., Clarendon Press: Oxford, 2006.

2. Rizvi, S. I.; Maurya, P. K.; Ann. N.Y. Acad. Sci. 2007, 1100, 373.

3. Lee, W. C.; Wang, C. J.; Chen, Y. H.; Hsu, J. D.; Cheng, S. Y.; Chen, H. C.; Lee, H. J.; J. Agric. Food Chem. 2009, 57, 2206.

4. Dalle-Donne, I.; Rossi, R.; Giustarini, D.; Milzani, A.; Colombo, R.; Clin. Chim. Acta. 2003, 329, 23.

5. Levine, R. L.; Garland, D.; Oliver, C. N.; Amici, A.; Climent, I.; Lenz, A. G.; Ahn, B. W.; Shaltiel, S.; Stadtman, E. R.; Methods Enzymol. 1990, 186, 464.

6. Witko-Sarsat, V.; Friedlander, M.; Capeillère-Blandin, C.; Nguyen-Khoa, T.; Nguyen , A. T.; Zingraff, J.; Jungers, P.; Descamps-Latscha, B.; Kidney Int. 1996, 49, 1304.

7. Cakatay, U.; Kayali, R.; Uzun, H.; Clin. Exp. Med. 2008, 8, 51.

8. Cao, G.; Booth, S. L.; Sadowski, J. A.; Prior, R. L.; Am. J. Clin. Nutr. 1998, 68, 1081

9. Rizvi, S. I.; Zaid, M. A.; Anis, R.; Mishra, N.; Clin. Exp. Pharmacol. Physiol. 2005, 32, 70.

10. Scalbert, A.; Manach, C.; Morand, C; Remesy, C.; Crit. Rev. Food. Sci. Nutr. 2005, 45, 287.

11. Shakibaei, M.; Harikumar, K. B.; Aggarwal, B. B.; Mol. Nutr. Food Res. 2009, 53, 115.

12. Yang, Y. B.; Piao, Y. J.; Acta Pharmacol. Sin. 2003, 24, 703.

13. Sun, A. Y.; Wang, Q.; Simonyi, A.; Sun, G. Y.; Neuromol. Med. 2008, 10, 259.

14. Gedik, E.; Girgin, S.; Ozturk, H.; Obay, B. D.; Ozturk, H.; Buyukbayram, H.; World J. Gastroenterol. 2008, 14, 7101.
15. Pandey, K. B.; Rizvi, S. I.; Phytother. Res. 2010, 24, S11.

16. de la Lastra, C. A.; Villegas, I.; Biochem. Soc. Trans. 2007, 35, 1156.

17. Athar, M.; Back, J. H.; Kopelovich, L.; Bickers, D. R.; Kim, A. L.; Arch. Biochem. Biophys. 2009, 486, 95.

18. Pandey, K. B.; Mishra, N.; Rizvi, S. I.; Nat. Prod. Commun. 2009, 4, 221.

19. Kitajima, H.; Amaguchi, T.; Kinoto, E.; J. Biochem. 1990, 108, 1057.

20. Hawkins, C. L.; Morgan, P. E.; Davies, M. J.; Free Radical Biol. Med. 2009, 46, 965

21. Berlett, B. S.; Stadtman, E. R.; J. Biol. Chem. 1997, 272, 20313.

22. Uchida, K.; Stadtman, E. R.; J. Biol. Chem. 1993, 268, 6388.

23. Witko-Sarsat, V.; Friedlander, M.; Nguyen Khoa, T.; CapeillereBlandin, C.; Nguyen, A. T.; Canteloup, S.; Dayer, J. M.; Jungers, P.; Drueke, T.; Descamps-Latscha, B.; J. Immunol. 1998, 161, 2524.

24. Kaneda, H.; Taguchi, J.; Ogasawara, K.; Aizawa, T.; Ohno, M.; Atherosclerosis (Amsterdam, Neth.) 2002, 162, 221.

25. Rokutan, K.; Johnston Jr., R. B.; Kawai, K.; Am. J. Physiol. 1994, 266, G247.

26. Iciek, M.; Chwatko, G.; Lorenc-Koci, E.; Bald, E.; Włodek, L.; Acta Biochim. Pol. 2004, 51, 815.

27. Sengottuvelan, M.; Viswanathan, P.; Nalini N.; Carcinogenesis 2005, 27, 1038.

28. Wang, Z.; Huang, Y.; Zou, J.; Cao, K.; Xu, Y.; Wu, J. M.; Int. J. Mol. Med. 2002, 9, 77.

29. Floreani, M.; Napoli, E.; Quintieri, L.; Palatini, P.; Life Sci. 2003, 72, 2741

30. Baur, J. A.; Sinclair, D. A.; Nat. Rev. Drug Discovery 2006, 5, 493.

31. Pace-Asciak, C. R.; Rounova, O.; Hahn, S. E.; Diamandis, E. P.; Goldberg, D. M.; Clin. Chim. Acta. 1996, 246, 163.

32. Blardi, P.; De Lalla, A.; Volpi, L.; Di Perri, T.; Drugs Exp. Clin. Res. 1999, 25, 105

33. Walle, T.; Hsieh, F.; De Legge, M. H.; Oatis Jr., J. E.; Walle, U. K.; Drug Metab. Dispos. 2004, 32, 1377.

34. Woods, A. A.; Linton, S. M.; Davies, M. J.; Biochem. J. 2003, 370,729

Received: July 19, 2009

Web Release Date: March 1, 2010 